\title{
1 Introduction: the policy context of urbanization
}

\author{
M. Pacione
}

\section{Introduction}

Urban policy is concerned with the management of urban change. It is a state activity that seeks to influence the distribution and operation of investment and consumption processes in the built environment. It is important to realize, however, that urban policy is not confined to activity at the urban scale. National and international economic and social policies are as much urban policy, if defined by their urban impacts, as land use planning or urban redevelopment. In effect urban policy is often made under another name. Urban policy is dynamic. Its formulation and implementation form a continuing process, not an event. Measures that are introduced cause changes that may resolve some problems but create others for which further policy is required. Furthermore, only rarely is there a simple optimum solution to an urban problem. More usually a range of policy options exists for the consideration of decision makers and urban managers.

Urban policy is the product of the power relationship between the different interest groups that constitute a particular social formation. Foremost among these actors are the state, both local and national, and capital in its various fractions. Capital and state pursue specific goals, which may be either complementary or contradictory. For capital, the prime directive is profit maximization. The state, on the other hand, in addition to facilitating the process of accumulation, must also satisfy the goal of legitimation. These political and economic imperatives have a direct influence on the nature of urban policy. Urban policy is also conditioned by external forces operating within the global economic system, as well as by locally specific factors and agents.

Understanding the policy context of urbanization and urban restructuring in Western society requires a comparative examination of the particular manifestations of urban development processes in different countries and localities, informed by an appreciation of the macropolitical economy.

In this introductory chapter I provide a context within which subsequent chapters in the book can be positioned and more clearly interpreted. I begin by outlining the main tenets of the capitalist development process that underwrites urban restructuring in Western cities. I then consider the relationship between ideology and urban policy, and identify different forms of urban policy. Based on this conceptual framework I discuss the particular construction of urban policy in the UK and the USA, and the significance of urban policy and planning in the reconfiguration of urban space. The discourse on urban policy and planning is interwoven with references to key processes and challenges in contemporary Western urban society - including uneven development, poverty and disadvantage, urban politics and governance, public-private partnerships and urban change, the role of property-led regeneration, the cultural economy of cities, suburbanization and urban sprawl, and sustainable urban development - all of which are amplified in the chapters that follow. 


\section{International handbook of urban policy}

\section{The restructuring of urban space}

Uneven development is an inherent characteristic of capitalism that stems from the propensity of capital to flow to locations that offer the greatest potential return. The differential use of space by capital in pursuit of profit creates a mosaic of inequality at all geographic levels from global to local. Consequently, at any one time certain countries, regions, cities and localities will be in the throes of decline as a result of the retreat of capital investment while others will be experiencing the impact of capital inflows (Smith and Feagin, 1987; Smith, 1988; Pacione, 1997). The older industrial cities in the advanced economies have been among the biggest losers in the global investment competition. Cities such as Pittsburgh and Cleveland, Glasgow and Liverpool have experienced the strains of recession and contraction as a result of the new international division of labour and the deindustrialization of traditional economies. In stark contrast, global command cities such as London or Tokyo are booming and experiencing the diverse problems caused by concentration of activities. Centrally planned economies have not been immune to the forces of change emanating from the operation of the global economic system either. In the former Soviet Union urban policy makers must negotiate the transition towards a 'post-Socialist' city, characterized by capitalist tendencies such as suburbanization, gentrification and sociospatial polarization. In the Third World, as a direct result of the uneven pattern of development within most countries, urban areas are growing at an explosive rate as a consequence of rural-urban migration. Given the comparatively low levels of urbanization in many regions, such as Africa, and the limited resource base of most Third World states, the urban crisis seems destined to deepen.

The central importance of capital in this process of urban restructuring is axiomatic, but it is important to avoid the fallacy of economic determinism that, paradoxically, is shared by the conservative New Right and the Marxist Left, and is enshrined in many contemporary interpretations of globalization. Technical and economic processes, the material forces of production, are not the only determinants of urban growth and decline. The policies of the local and national state can exert at least an equally important influence on urban change. Regulatory and tax policies shape the environments that attract or repel investors, decisions about public investment determine whether infrastructure will be rebuilt or allowed to deteriorate, government procurement policy stimulates the private economy, and intergovernmental transfer payments can prevent the total collapse of a local economy (Budd and Whimster, 1992; Sassen, 1994; Mohan, 2000).

A structural interpretation of urban change that emphasizes the omnipotent logic of the capitalist (or any other) mode of production also affords insufficient consideration to the way in which general processes are embedded in and modified by historically specific national and local settings (Persky and Weiwel, 1994; Cox, 1997; Eade, 1997). For example, it is the combination of economic forces with historically specific social and political processes that produces the particular form of uneven development found in the USA. Sprawling suburban development, widespread urban fiscal stress and extreme class segregation of residential communities are not reproduced to the same extent in other capitalist states. In Europe, for example, suburban sprawl is less extensive, the central state finances a larger share of local government budgets thereby mediating local fiscal stress, and the upper social strata are less anti-urban in lifestyle and residential location. The restructuring of urban space is best understood as the outcome of actions taken by 
both economic and political actors operating within a complex and changing matrix of relations between global and national political-economic forces, and national and local social and political processes.

\section{Ideology and urban policy}

The form of urban policy employed depends on the problem to be tackled and, most fundamentally, on the ideological position of the state. The outcome of the power relationship between capital and polity can be usefully translated into four ideological regimes (Fainstein and Fainstein, 1982; King, 1983; Judd and Swanstrom, 1998). In two of these - the market capitalist (or market conservative) and the corporate fascist - capital as a whole occupies a hegemonic position that enables it to maximize the benefits of state programmes and limit the costs. In the first, the degree of state penetration of the means of production is low, involving, for example, tax reductions, employment subsidies, urban renewal and designation of free trade zones. In the second, state involvement is more direct and may include controls over investment decisions, wage structure, union power and the banking system. The third type of policy regime the liberal democratic or welfare state liberalism - incorporates working-class interests through the dominance in the governing coalition of a conservative party of the Left (such as the British Labour Party or the German Social Democrats). The final ideological position is represented by a social democratic regime dominated by a leftist workingclass party favouring direct control of production to channel income benefits to labour rather than to capital. Whichever ideology is dominant in a country largely determines the form of urban policy. During the postwar period, in advanced economies particular attention has focused on the changing strength of market capitalism and welfare state liberalism.

Advocates of market capitalism (as espoused by Reaganomics in the USA and Thatcherism in the UK) view the production of unevenly developed cities and regions as the inevitable outcome of technological change within an economic system that readily adapts to innovation. The negative sociospatial effects of this restructuring that impinge on disadvantaged people and places are regarded as unavoidable consequences of a process that is of benefit to society as a whole. Since market forces are seen to be the most efficient allocators of capital and labour, state intervention is considered unnecessary. Policies involving social welfare expenditure and government financial aid to declining cities are regarded as harmful because they anchor low-wage workers to sites of low employment opportunity, discourage labour force participation and inhibit labour mobility. Welfare state liberals, on the other hand, while accepting the central role of the market, acknowledge that the institutional and cyclical 'market imperfections' that have left certain people and places in prolonged economic distress must be rectified by compensatory government policies.

\section{Forms of urban policy}

Policies vary considerably between countries, reflecting the institutional environment in which they are set and the procedures and instruments selected for implementation. Nevertheless it is possible to distinguish several general forms of urban policy. The first consists of policies designed to guide urban growth and change at a national scale, i.e. between urban regions. The second consists of policies to guide urban growth 
and change at an intraregional or metropolitan scale, i.e. within urban regions. Third, in some federal countries (such as Australia, Canada, Germany, India and the USA) there may be an intervening level of policy development at the state or provincial level. Finally, there are 'non-urban' policies that indirectly and often inadvertently affect urban restructuring.

Two broad kinds of national urban policies may be identified. The first refers to attempts to restrain the growth of core city-regions and promote growth in peripheral regions. These policies have been applied to cities such as London, Paris and Tokyo with varying levels of success. Since the mid-1970s, however, the reduction in economic and population growth in many cities of the developed world and increased concern for declining inner-city areas have questioned the general need for growth constraint policies. The second type of national policy seeks to reshape the settlement system. In the 1960s and early 1970s many countries adopted growth pole strategies (for example, the French metropoles d'équilibre), in part as a response to metropolitan restraint policies. By the late 1970s, however, these policies had lost favour because of political opposition from those small and medium-sized towns not designated as growth centres, and the fact that in practice the geographic spread effects of the policy were less than postulated by theory. More recently, governments have employed a range of national policy initiatives to direct investment into declining industrial cities. These have typically included tax concessions, employment incentives, infrastructure improvements, selective public sector procurement policies and creation of special economic zones (such as enterprise zones, simplified planning zones and urban development corporations).

Although not all countries have national urban strategies, most have attempted to influence the form of urban development at the metropolitan scale (Peterson and Lewis, 1986; Stegman, 1995; Hill, 2000). For much of the postwar period such policies have aimed to channel development in order to stem the physical expansion of the built-up area, avoid excessive loss of valuable agricultural land, ensure more efficient use of infrastructure and reduce congestion in the urban core. A variety of housing, transport, land use and development control policies has been employed in pursuit of these goals. Since the late 1970s, policy emphasis at the metropolitan level has also turned to the steering of employment and investment into inner urban areas or to new suburban sub-centres using a combination of controls on and inducements to the private sector.

Of at least equal importance to these explicit urban policies, in terms of their influence on urban development, are those national policies that are urban in neither focus nor intent but that significantly affect the form and rate of urban change. These 'non-urban' policies include the following.

- Fiscal policies such as tax relief on mortgage interest payments affect urban development. In the USA the availability of tax relief and federal mortgage insurance for new single-family dwellings was a major stimulus to low-density suburban development in the postwar period.

- Industrial policies including decisions to support certain industries (such as steel production) or expand certain public expenditure (such as defence) have a differential spatial impact since relevant activities are unequally distributed among cities and regions. 
- Equalization policies that result in intergovernmental transfers operate in favour of some urban areas above others.

- Transport policies can have significant urban effects. For example, the US interstate highway programme greatly encouraged postwar metropolitan sprawl and stimulated the growth of cities whose accessibility was enhanced.

- Even agricultural policies can have an urban impact. Structural policies to promote the capitalization of agriculture directly affect the size of the agricultural labour force and therefore rural-urban migration. This is of particular significance in the Third World today.

- The impact of immigration policies tends to be concentrated on particular cities. Flows of migrants profoundly affect urban labour markets, housing programmes and social structures.

The implementation of urban policy under differing ideological regimes can be illustrated with reference to postwar developments in the UK and the USA.

\section{Urban policy in the UK}

We can identify five major phases in British postwar urban policy (Oatley, 1998).

\section{The physical redevelopment phase}

From the end of the Second World War until the late 1960s, urban problems were seen largely in physical terms. The policy response to issues of housing quality and supply, transport and industrial restructuring focused on slum clearance and comprehensive redevelopment strategies, and the planned decentralization of urban population via regional policy and New Town development.

\section{The social welfare phase}

In the early 1970s, empirical research highlighted the incidence of poverty within the UK's cities as the long postwar boom faltered. Emphasis was placed on supplementing existing social programmes to improve the welfare of disadvantaged individuals and communities. Influenced by US initiatives, such as the Head Start project developed as part of the Model Cities programme, a range of area-based experimental schemes was introduced during the 1970s. These 'Urban Programme' initiatives, which included educational priority areas and community development projects (Edwards and Batley, 1978), operated from a 'culture of poverty' perspective (under which poverty is held to be self-reproducing) and aimed to give deprived communities the capacity to solve their own problems. The widespread increase in unemployment in the mid-1970s, in the wake of the Arab oil embargo and world recession, made it clear, however, that the scale of urban deprivation could not simply be the result of the inadequacies of the poor. An alternative 'structural' explanation of poverty was enshrined in the final report of the Community Development Project. This rejected a social pathological view of deprivation in the conclusion that

there might certainly be in those areas a higher proportion of the sick and the elderly for whom a better co-ordination of services would undoubtedly be helpful, but the vast majority were ordinary, working-class men and women who, through forces outside their control, happened 


\section{International handbook of urban policy}

to be living in areas where bad housing conditions, redundancies, lay-offs and low wages were commonplace. (Community Development Project, 1977, p. 4)

It followed that to tackle the root causes of urban decline would require more than marginal adjustments to existing social policies. This was acknowledged by the 1977 White Paper on policy for the inner cities, which signalled a more broadly based approach to urban problems, combining economic, social and environmental programmes and involving new partnership arrangements between central and local government to provide a more coordinated response. The emphasis on improving the economic environment of cities was promoted in several ways, including a shift of attention from New Towns to urban regeneration and increased powers to enable local authorities to aid and attract industrial developments. The major vehicle for these measures was the expanded Urban Programme (Lawless, 1988). In practice, however, a concerted attack on the urban problem was undermined by the prerogatives of national economic policy, which led to reductions in local authority finance. The Conservative government elected in 1979 continued the concept of partnership but stressed the necessary involvement of the private sector.

\section{The entrepreneurial phase}

The advent of the Thatcher government in 1979 'witnessed the fracture of three main pillars upon which post-Second World War social democratic politics was constructed - Fordism, Welfarism and Keynesianism' (Gafficken and Warf, 1993 p. 71). The reorientation of urban policy by the New Right Conservative government was part of a wider agenda to restructure the UK economically, socially, spatially and ideologically around a new consensus of free market individualism and an unequivocal rejection of the social democratic consensus of the postwar Keynesian welfare state. As Martin (1988, p. 221) observed, the thrust of state policy shifted from welfare to enterprise:

the aim has been to reverse the post-war drift towards collectivism and creeping corporatism, to redefine the role and extent of state intervention in the economy, to curb the power of organised labour, and to release the natural, self-generative power of competitive market forces in order to revive private capitalism, economic growth and accumulation.

The Keynesian commitment to the macroeconomic goal of full employment was replaced by the objective of controlling inflation by means of restrictive monetary measures and supply-side flexibilization. From its inception, 'Thatcherism' was a doctrine for modernizing the UK's economy by exposing its industries, its cities and its people to the rigours of international competition in the belief that this would promote the shift of resources out of inefficient 'lame-duck' traditional industries and processes into new, more flexible and competitive high-technology sectors, production methods and work practices. The principal mechanisms for achieving this transformation centred on tax cuts and deficit spending, deregulation and privatization, all of which had geographically uneven impacts. At the urban level these three macroeconomic strategies were combined most strikingly in the concepts of the enterprise zone (EZ) and the urban development corporation (UDC).

As part of the broad political and economic agenda, urban policy was also used to restructure central government-local government relations. Five processes characterized the changes: 
- displacement involving the transfer of powers to non-elected agencies (e.g. UDCs), thereby bypassing the perceived bureaucracy and obstructiveness of local authorities;

- deregulation involving a reduction in local authorities' planning controls to encourage property-led regeneration (e.g. in EZs);

- the encouragement of bilateral partnerships between central government and the private sector;

- privatization, incorporating the 'contracting out' of selected local government services, housing tenure diversification, and provision for schools to 'opt out' of local education authority control; and

- centralization of powers through a range of quangos (quasi non-governmental organizations).

The competitive phase

By the early 1990s it was evident that the approach to urban policy pursued since 1979 had failed to reverse urban decline. The limitations of a property-based approach to regeneration had been exposed by a slump in the demand for property in the recession of 1989-91. As Turok (1992, p. 376) observed, although property development has potentially important economic consequences, it is 'no panacea for economic regeneration and is deficient as the main focus of urban policy'. Property development lacks the scope, powers and resources to provide the holistic approach required to tackle urban decline. Its limited perspective and goals are unable to guarantee a rise in overall economic activity in a locality and ignore important 'human issues' such as affordable housing, education and training, social exclusion and investment in basic infrastructure.

The government's response was to reconstruct urban policy around the initial catalyst' of competition. This era of competitive urban policy was heralded by the City Challenge initiative, which introduced competitive bidding among local authorities for urban regeneration funds. Successful schemes are managed by a multi-agency partnership involving the local authority along with the private, voluntary and community sectors. While local authorities appeared to have a greater role under this arrangement, in practice local autonomy was constrained by the underlying entrepreneurial ethos of the partnership organizations and by the need for successful bids to conform to central government guidelines.

\section{The Third Way}

The fifth phase of UK urban policy began in 1997 with the election of 'New Labour' committed to a political 'Third Way' (Levitas, 1998; Giddens, 2000) between the principles of Thatcherite neoliberalism and more traditional forms of social democracy and welfarism. This approach had clear links to policies of the New Democrats in the USA (Collinicos, 2001) and to several Scandinavian welfare states (Etherington and Jones, 2004). Introduction of Labour's Third Way marked a move away from the neoliberal era of policy under the Conservatives towards a situation in which greater attention is given to the social consequences of economic policy. In policy terms the key priorities include strengthening local and regional economies, increasing economic opportunities for deprived areas, rebuilding neighbourhoods and promoting sustainable development. 
Specifically, New Labour's CORA approach to urban policy is based on:

- Community - involvement, with greater public participation

- Opportunity - to work or to obtain training and education

- Responsibility - in the obligation of citizens who can work to do so

- Accountability - of governments to their publics.

In practice, urban policy initiatives have proliferated at such a rate since New Labour came to power that, in 2003, the then regeneration minister likened the policy maze to a bowl of spaghetti made up of diverse strategies and initiatives that cross different spaces, scales and policy areas. Collectively, while it represents Labour's attempt to generate a 'renaissance' in urban economic, social and community life, the 'monumental complexity' (Johnstone and Whitehead, 2004, p. 13) of New Labour's urban policy also presents a barrier to success.

For most of the past 25 years urban policy in the UK has been based on a market-led approach to urban development. Justification for the market-led approach to urban regeneration centres on the concept of 'trickle down', which argues that, in the longer term, an expanded city revenue base created by central area revitalization provides funds that can be used to address social needs. In practice, however, these funds are generally recycled into further development activity. Nowhere has a substantial trickle-down effect been demonstrated. The available evidence suggests that it is naïve to expect a 'morally aware' private sector to effect the revitalization of run-down urban areas. Private sector investment decisions are founded largely upon self-interest and not philanthropy. The privatization of urban development inevitably means accepting a policy of triage and concentrating on areas of greatest economic potential - with adverse consequences for other areas. In order to address problems of deprivation and disadvantage, urban policy must possess both a social and an economic dimension. It must be concerned as much about the distribution of wealth as about wealth creation. Such social criteria did not figure prominently in 'top-down' urban policy in the UK (and the USA) during the last quarter of the twentieth century.

\section{Postwar urban planning in the UK}

The importance of urban planning as a vehicle for carrying urban policy into practice varies between countries. The UK has established a powerful national planning system to guide urban change. The structure of modern urban planning in the UK was laid down in the 1947 Town and Country Planning Act (Cullingworth and Nadin, 2006). The basic principle enshrined in the 1947 Act is that of private land ownership but public accountability in use, so that landowners seeking to undertake development first had to obtain permission from the local planning authority. The local authority was also given the power to acquire land for public works by compulsory purchase on payment of compensation to the landowner. Local planning authorities were required to prepare and submit quinquennial development plans to the Ministry of Town and Country Planning indicating how land in their area was to be used. A second principle embodied in the 1947 Act was that of community gain, rather than individual gain, from land betterment. This meant that when land was developed, the increase in its value that resulted from the granting of planning permission was reserved for the community by the imposition of a 
100 per cent land development tax. Political opposition ensured that this provision was removed in 1952. Today, compulsory exaction of betterment values from land developers has been replaced by a system of negotiated agreements over 'planning gain' (Claydon and Smith, 1997), which represents the benefits that a local authority may require of a developer as a condition for receiving planning permission.

The primary objectives of the 1947 planning system at the city-region scale were urban containment, protection of the countryside, and the creation of self-contained balanced communities (e.g. New Towns). These goals were advanced by local authorities using the development plan and development control process; and by central government through the New Towns programme, supplemented by the Expanding Towns scheme (which enabled cities with problems of overcrowding to arrange overspill schemes with other local authorities). The first major changes to the 1947 planning system were contained in the 1968 Town and Country Planning Act. This sought to introduce greater responsiveness and flexibility to the plan-making process. The single development plan with its specific land-use focus and five-year life expectancy was replaced by a two-tier system of structure plans and local plans. Structure plans are comprehensive strategic statements designed to translate national and regional economic and social policies into the specific areal context of the local authority. Local plans apply the structure plan strategy to particular areas and issues, and make detailed provisions for development control.

Most commentators would agree that the 1947 planning system has achieved its objectives: postwar suburban growth has been contained to the extent that coalescence of adjacent cities has been prevented and good-quality agricultural land protected. The major mechanism of green belts around the large cities has prevented peripheral sprawl, although they have contributed to inflation in land and housing prices in existing settlements within the green belt and provoked an ongoing conflict between developers and planners over the availability of land for housing (Adams and Watkins, 2002). Also, the green belt has been powerless in the face of increases in transport technology and in the length of acceptable commuting journey, which have seen some residential development leapfrog into settlements beyond the green belt. But, in general, the UK planning system has prevented the kind of scattered urban development in evidence around cities in North America.

\section{Urban policy in the USA}

Federal involvement in the economic and social life of urban America, in terms of policy formulation, increased during the Depression of the 1930s, when Franklin D. Roosevelt's New Deal programme supported poor citizens by providing a minimum wage, unemployment insurance and social security, and middle-class Americans via programmes such as the Federal Housing Administration's scheme for below-market-rate mortgages. Following the Second World War the role of the federal government in urban life expanded even though policies were not specifically urban by designation - a particular example being the way in which FHA mortgage insurance and federal funding of the interstate highway system contributed to the suburbanization of American cities. During the 1960s the number of federal programmes aimed specifically at the city increased in response to the growth of urban problems, ranging from poverty and civil rights riots to the financial crises of urban governments. In 1965 the Department of Housing and Urban Development was established as part of Lyndon B. Johnson's Great 
Society. New federal programmes included the War on Poverty (which was intended to extend beyond the basic income security programmes of the New Deal era to job training for those unable to find work), the Community Action Program (designed to facilitate the maximum feasible participation of residents in the local organization of anti-poverty services) and the Model Cities Program (which aimed to produce the comprehensive renewal of urban slum neighbourhoods in 150 selected cities).

The era of 'creative federalism' and its wide range of categorical urban programmes was ended by Richard Nixon's (1969-74) concept of new federalism. The stated policy objective was to allow localities to take spending decisions on the basis of local knowledge. Accordingly, the two main initiatives were a system of general revenue sharing which provided cities with funds according to a needs-based formula, and the amalgamation of individual programmes into a block grant, the most significant of which was the Community Development Block Grant (CDBG), which consolidated seven categorical grants, including those for urban renewal and the Model Cities Program. In terms of social impact there is evidence that, owing to the high level of local discretion, up to 40 per cent of the CDBG expenditure occurred in wealthier urban areas (Heinig, 1985). For example, the town of Little Rock, Arkansas, used $\$ 150000$ from the CDBG to build a tennis court in a wealthy area.

The introduction of the Urban Development Action Grant (UDAG) programme under the Carter Administration aimed to encourage private investment in distressed communities by using federal grants to leverage private money into public-private sector development schemes. The reorientation of urban policy towards private-sectorled urban economic development was extended by the subsequent New Right administrations of Ronald Reagan and George Bush, who, like Margaret Thatcher in the $\mathrm{UK}$, believed in the power of unfettered market forces to create a prosperous economy within which benefits would 'trickle down' to most sections of society, leaving residual problems to be addressed by specific people-oriented as opposed to place-oriented policies. Programmes considered counterproductive were reduced or eliminated, including UDAGs and subsidized housing. The withdrawal of government intervention in urban policy and planning was reflected by a 59 per cent reduction in federal spending on US cities between 1980 and 1992.

Following the coming to power of the Clinton Administration in 1993, urban policy was spearheaded by the concept of empowerment zones and enterprise communities (McCarthy, 2003). Designated EZ/ECs receive federal investment plus tax incentives to help create employment. To be eligible for the programme, cities were expected to have secured a commitment of private sector investment and to involve the community in the planning and implementation of the initiative. By 2000, 22 EZs and 45 ECs had been designated. A further $8 \mathrm{EZs}$ were ordered in 2002, together with 28 Urban Renewal Communities in which tax incentives (but not direct federal funding) are available to stimulate local private sector job growth and economic development. The Detroit URC area, for example, covers 25 square miles and contains 120,000 residents, 40 per cent of whom live in poverty. Use of tax-based incentives to promote urban regeneration is a key element of US urban policy. Major initiatives involving taxation measures include EZs at federal and state level, tax incremental financing (TIF) at city level, and business improvement districts at neighbourhood level (McGreal et al., 2002).

The neoliberal trajectory of US urban policy over recent decades was continued 
during the administration of G.W. Bush with introduction of legislation to involve faithbased and community organizations in provision of social services, re-authorization of the 1996 Personal Responsibility and Work Opportunity (Workfare) Act, and passage of the No Child Left Behind Act to address the problems of poor-quality public schools.

\section{Urban planning in the USA}

By contrast with the situation in the UK, in the USA there is no national system of planning in the sense of a common framework with a clearly defined set of physical, social and economic objectives. Planning is not obligatory, and together with the fragmented structure of local government - in addition to the federal government and 50 states, there are about 8000 counties, 18000 municipalities and 17000 townships each with the power to plan or regulate land use, i.e. an average of 760 per state - this means that the content of planning is both local and variable from place to place. In principle a range of techniques for controlling urban growth and land use is available, but in practice the major tool employed is land-use zoning. Specific urban problems, such as provision of low-income housing, are addressed through federal policy.

The first comprehensive zoning ordinance was passed in New York in 1916. The judgment of the US Supreme Court in 1926 that zoning did not infringe the Fourteenth Amendment to the Constitution (which protects against property being taken without due process of law) led to widespread adoption of the technique. Under this procedure, the effective control of land use was transferred from the state to the municipalities and townships, which were thereafter permitted to limit the types of development on land within their boundaries (Nelson, 1980), including control over the height, bulk and area of buildings constructed after the enactment of zoning regulations. The purposes of such controls were to minimize problems of congestion, fire hazard, shading by high buildings; to control population density; to ensure provision of urban services; and to promote the general welfare of the public. In practice there are many forms of zoning (Jackson, 1981; Cullingworth and Caves, 2003). Common forms of land-use zoning in the USA include cluster zoning and planned unit development used extensively by residential community developers, and incentive zoning that (like the planning gain mechanism in the UK) operates as a means of obtaining private sector provision of public amenities by offering zoning bonuses such as extra levels in a multi-storey building. This variety, and the underlying presumption in favour of development, means that controls over market-induced physical growth and change are much weaker in the USA than in the UK.

The effects of land-use zoning on urban development in the USA have generated significant debate. Critics of zoning maintain that it is unnecessary, since market forces will produce a fair segregation of land uses. It is open to corruption, particularly in respect of variances (permitted modifications or adjustments to the zoning regulations). It can lead to premature use of land resources by owners who fear an unfavourable zoning change (downzoning). It is unequal in its effect, since a piece of property zoned for commercial use provides its owner with windfall profits at the expense of neighbours who must bear the costs of increased traffic noise and congestion. The most vociferous criticism is reserved for the practice of exclusionary zoning whereby suburban municipalities adopt legal regulations designed to preserve their jurisdictions against intrusion of less desired land uses. Regulations requiring large lots, excessive floor space, three or more bedrooms, 
or excluding multiple-unit dwellings, high-density development or mobile homes, all serve to maintain high-cost housing and effectively exclude lower-income population. Supporters of zoning, on the other hand, argue that it is a flexible tool and an effective means of allowing local residents to determine part of the character of their neighbourhood. Certainly the widespread use of zoning during much of the twentieth century has helped to determine the current land-use structure of metropolitan America.

The characteristic low-density sprawl of suburban America has provoked a number of 'growth management' policy responses designed to counteract this expansive form of development.

\section{Growth management in the USA}

A wide range of growth management strategies has been employed by cities and states in an attempt to moderate the negative effects of urban sprawl (Daniels, 1999). Many of the techniques in use seek to link residential development to infrastructure provision. The town of Ramapo, New York, 35 miles from downtown Manhattan, introduced a timed growth plan in the late 1960s to ensure that residential development proceeded in phase with provision of municipal services. To this end, developers were required to obtain a permit for suburban residential development. Where the required municipal services were available, the permit was granted but elsewhere development could not proceed until the programmed services had reached the location or were provided by the developer. The town of Petaluma, 40 miles north of San Francisco, introduced, in 1972, an annual development quota of 500 dwellings. Applications to build were assessed against criteria that included access to existing services with spare capacity, design quality, open space provision, inclusion of low-cost housing, and provision of public services. The city of Napa, CA introduced an urban limit line intended to cap the population at 75000 by the year 2000. Beyond the boundary essential public services would not be provided (the actual population in 2000 was 72585 ). Several Californian cities, including San Diego and San Jose, have passed laws requiring voter approval for proposed developments. While 'voter requirements' have not prevented new development in the long run, they have affected the power balance between 'pro-growth' developers and 'slow-growth' community interest groups, and have provided current residents with some compensation for the negative aspects of growth (Gerber and Phillips, 2004). A related anti-growth strategy is encapsulated in the concept of smart growth (Burchell et al., 2000). The smart thing about the smart-growth movement that has emerged in the USA since the mid1990 s is that while advocates share many of the goals of previous anti-sprawl efforts, their language and methods are more pragmatic and inclusive. Rather than appealing narrowly to environmental sensibilities, the focus is on broader quality-of-life issues based on a more comprehensive view of the urban development process. Many of the principles of smart growth (such as attractively designed, mixed land use, compact communities) overlap with those of New Urbanism (Talen, 2005).

\section{Public-private partnership}

The entrepreneurial thrust of urban policy in the USA and UK during the 1980s was underwritten by cooperation between the government and the private sector. This approach owed much to experience in North America's cities, where the practice of public-private partnership in urban regeneration dates back more than half a century. 
Following the Second World War, US city governments, faced with growing blight in downtown areas and attracted by federal funding from the urban renewal programme, joined forces with private developers in 'quasi-public' redevelopment corporations that were able to sidestep conventional procedures for municipal policy making. By the 1960s these business-government partnerships had produced a range of downtown redevelopments including Pittsburgh's Golden Triangle, Baltimore's Charles Centre and Minneapolis's Nicolett Mall. In the 1970s and 1980s, prompted by the problems of deindustrialization and fiscal distress, city governments moved beyond single-project collaboration with developers. In the context of heightened inter-city competition for private investment, municipal governments, especially those with high-profile 'boosterish' mayors, became entrepreneurial, providing extensive subsidies and incentives to attract developers, and often becoming co-developers of more risky redevelopment projects. Public-private partnerships became the cornerstone of economic development strategies of virtually all US cities - strategies that centred on the creation of a good business climate (Levine, 1989). This trend is exemplified by the 'Rouse-ification' of downtowns across the USA. With its production of 'festival marketplaces' in, for example, Boston (Faneuil Hall), New York (South Street Seaport), Baltimore (Harborplace), Milwaukee (Grand Avenue Mall) and St Louis (Union Station), the Rouse Company became the leading downtown developer in the country.

The distributional impact of these projects has been typically uneven, with, in most cities, redeveloped downtowns resembling 'islands of renewal in seas of decay' (Berry, 1985, p. 69). Baltimore's Inner Harbor is heralded as a national model of public-private waterfront reclamation, but during the course of its redevelopment the poverty rate increased in 90 per cent of the city's non-white neighbourhoods (Levine, 1987). A principal reason for such contrasts is that downtown corporate centres based on advanced services and tourism often have only limited links to a local economy and rarely generate economic development in surrounding neighbourhoods. In addition, since the kinds of jobs created are unlikely to provide employment opportunities for urban poor and minority populations, many of the benefits of redevelopment are taken up by suburban commuters. The efficacy of relying on the 'trickle-down' effect, rather than public targeting to encourage economic development in the most distressed urban neighbourhoods, is open to question.

\section{Property-led regeneration}

Property-based development has played a prominent role in urban regeneration projects undertaken by public-private partnerships. During the 1980s property-led regeneration assumed a central place in urban policy, with the key role of the private sector demonstrated most visibly in flagship projects such as the redevelopment of Canary Wharf in London's Docklands or the transformation of Baltimore's waterfront (Malone, 1996). However, property development alone is an insufficient basis for urban economic regeneration. Although property development and rehabilitation can improve a residential environment and construction projects can provide scope for employment, a property-led approach fails to consider the crucial issues of (a) development of human resources, such as education and training, which have long-term effects on people's incomes and employment prospects; (b) the underlying competitiveness of local production; and (c) investment in infrastructure, such as transport and communications. 
The value of property-led redevelopment is locally contingent. A strong role for property-based measures may be appropriate where there are problems associated with land or building conditions or where shortages of floorspace restrict inward investment and indigenous growth. Nevertheless, uncontrolled property development may drive up local property prices, encourage land speculation and displace existing economic activities and populations unable to afford higher rents. More generally, the capital market's preference for short-term moneylending and speculation rather than longer-term investments can divert finance capital into property and away from more productive activities such as manufacturing.

Nowhere has the impact of property-led urban redevelopment been more evident than in the global cities of London and New York, where, during the 1980s in particular, the growth of the financial services industry and concomitant expansion of office space interacted to engineer a major restructuring of urban space (Fainstein, 1994). By the end of the 1980s London was witnessing the largest office-building boom in its history as a result of the Conservative government's opening up of a once highly regulated property development arena for speculative ventures. Much of the new development appeared in the traditional heart of the City, which sought to protect itself from a leakage of financial sector activity to European rivals such as Frankfurt and Paris, as well as to the emerging Docklands, with its flagship development at Canary Wharf (Merrifield, 1993). The regeneration of the London Docklands is part of a longer 20-year strategy to redevelop the Thames Gateway subregion stretching 32 miles $(52 \mathrm{~km})$ from the old docklands to the Thames estuary (Church and Frost, 1995).

\section{Cultural industries and urban reconstruction}

The cultural economy of post-industrial/postmodern cities has assumed increasing importance (Scott, 1997). Cultural production embraces activities such as printing and publishing, film production, radio, television and theatre, libraries, museums and art galleries. High fashion, tourism and sports-related activities are also included in some definitions of the cultural industries sector (Mort, 1996). Such activities cut across the conventional production-consumption divide, blur the distinction between the functions of cities as centres of production and consumption, and illuminate the post-industrial/postmodern concept of flexible specialization. Los Angeles represents the largest cultural industries economy in North America, if not the world. In Britain the coincidence of production and consumption activity in 'consumption spaces' is seen in the regeneration of favoured areas such as Sheffield's cultural industries quarter with an emphasis on media production (Oatley, 1996), and Nottingham's lace market quarter, with its focus on fashion, design and media industries (Crewe and Beaverstock, 1998). The development of cultural industries quarters in contemporary cities has also involved the redevelopment of past urban landscapes as heritage areas as in the Gastown district of Vancouver, Albert Dock in Liverpool and the Merchant City in Glasgow. As urban places compete within the global economy for limited investment funds, their success often depends on the conscious and deliberate manipulation of culture in an effort to enhance their image and appeal. Critics of cultural-based strategies for urban renewal have pointed to a number of problem issues, including the uneven distribution of benefits and costs for the urban society as a whole. 


\section{Urban tourism and downtown redevelopment}

Tourism, along with finance and business services, is one of the fastest-growing components of the service sector. In many post-industrial cities the 'visitor economy' is of increasing importance, and promotion of tourism and leisure is a central element of downtown revitalization strategies. Las Vegas, the archetypal postmodern 24-hour consumption space, attracts over 46 million visitors annually. In the UK, the city of Glasgow has used arts and special events (such as its designation as European City of Culture, 1990) to re-brand its image from that of a declining industrial city, and increase visitor numbers (Law, 2002). Advocates of urban tourism development also identify wider benefits for cities. It is argued that advertising the city as a tourist destination and engaging in place promotion events (such as arts festivals, sports events and world fairs) benefit efforts to attract footloose economic activities. A revitalized inner city may also draw middle-class residents back into the centre, while new facilities constructed partly to attract tourists will also be available to local residents. Critics of tourist-based development contend that the industry provides only low-paid and seasonal work. However, many of the components of urban tourism, such as conferences, experience only minor seasonal variations. The industry also provides skilled employment at a management level, while the availability of low-skilled employment in centrally located tourist enterprises may benefit local populations. A further criticism concerns the possible diversion of public funds from services of direct benefit to resident groups, and the risk that cities may subsidize loss-making visitor attractions for the benefit of private businesses. In a number of US cities the force of these criticisms has been reduced by use of a room tax or sales tax that transfers development costs to visitors. Calculation of the costs and benefits of urban tourism is complicated by the fact that the impact is spread across many sectors from the visitor attractions to shops and transportation. Individual city authorities must decide whether the balance is right for them as they seek to compete successfully in the global economy of the early twenty-first century.

\section{Sustainable urban development}

Increasingly, urban policy and planning is required to adopt a long-term prospective role. This is particularly so when society, in managing urban change, seeks to strike a balance between economic priorities on the one hand and social and environmental priorities on the other. This issue is central to the question of sustainable urban development that aims to meet 'the needs of the present without compromising the ability of future generations to meet their own needs' (Brundtland Commission, 1987). The concept of urban sustainability comprises five key dimensions:

- Economic sustainability - the ability of the local economy to sustain itself without causing irreversible damage to the natural resource base on which it depends. This implies maximizing the productivity of a local (urban or regional) economy not in absolute terms (e.g. profit maximization), but in relation to the sustainability of the other four dimensions. The difficulty of achieving economic sustainability in capitalist societies is compounded by economic globalization that is promoting competition among cities, and between cities and their surrounding regions.

- Social sustainability - a set of actions and policies aimed at the improvement of quality of life and at fair access to and distribution of rights over the use and 
appropriation of the natural and built environment. This implies the improvement of local living conditions by reducing poverty and increasing satisfaction of basic needs.

- Natural sustainability - the rational management of natural resources and of the pressures exerted by the waste produced by every society. Overexploitation of natural capital and growing inequality in access to, and rights over, the natural resources of a city or region compromises the sustainability of natural capital.

- Physical sustainability - the capacity of the urban built environment to support human life and productive activities. Crises of physical sustainability are evident particularly in metropolitan areas of the Third World as a result of the imbalance between in-migration of population and the 'carrying capacity' of the cities.

- Political sustainability - the democratization and participation of the local civil society in urban governance. Attainment of this goal may be undermined by the increasing influence of non-local and market forces in urban change.

The ethos of sustainable development policy in the UK (and in the USA) is to move towards sustainable urban development within the context and standards of living commensurate with a developed world urban economy. This policy perspective is embedded in a belief that environmental costs may have to be accepted as the price of economic development (HMG, 1994); that social and economic dimensions of sustainable urban development are as important as environmental and resource-use issues (HMG, 1999); and in a commitment to high and stable levels of economic growth and employment (HMG, 2005). This governmental ethos is indicative of a more general national population view of the place of sustainable development in urban development. The rhetoric of sustainable development should not cloud the fact that most people will not relinquish voluntarily a cherished lifestyle. Further, the goal of sustainability is not an integral element of market capitalism and will inevitably encounter opposition from other competing interests.

Realization of a sustainable and liveable city requires both an integrated planning and decision-making framework, and a fundamental shift in traditional values and perspectives. There needs to be a change in focus from curative measures such as pollution reduction to measures based on prevention, from consumption to conservation, and from managing the environment to managing the demands on the environment. This will require change at the individual, community, business and urban levels.

Despite the difficulty of translating the rhetoric of sustainable urban development into policy reality, it is evident that, given the increasing numbers of people living in urban settlements, strategies designed to substitute sustainable development for unsustainable growth have the potential to exert a major influence on the future form and function of cities in the twenty-first century.

\section{Challenges for urban policy}

The contemporary world is an urban world. This is apparent in the expansion of urban areas and the extension of urban influences across much of the habitable surface of the planet. Today, for the first time in the history of humankind, urban dwellers outnumber rural residents. Current trends in world urbanization, the increasing number and size of cities, and the deterioration of many urban environments have placed a particular 
responsibility on policy charged with the management of urban change. The extent to which policy can meet this challenge depends on a variety of factors. These include the nature of the problem to be addressed, the organizational, institutional and fiscal framework of the country, the effect of external forces such as 'non-urban' policies and those emanating from the global political economy, and the power balance between capital and polity. The variability of policy environments in the modern world ensures that there is no single optimum approach to the formulation and implementation of urban policy.

While Western cities evolve towards a post-industrial postmodern future, most Third World cities are striving to attain the characteristics of a modern industrial city. These differences generate particular problems within each setting. Among the most pressing challenges for urban policy in the developed realm are those related to the ongoing process of urban expansion highlighted by the emergence of edge cities and ex-urbs within a polycentric urban region; fiscal and political stress between core cities and suburbs; increased sociospatial polarization within the post-industrial city and the accompanying need for urban policies to accommodate the growing diversity among urban populations; the impact of new telecommunications technology on urban form; and progress towards a sustainable city for the twenty-first century that reduces urban demands on and pollution of the natural environment. In the context of the Third World city urban policy makers are confronted by challenges of 'over-urbanization', including the poverty endured by the mass of the urban population; a widespread lack of decent housing, health care and other social services; and serious infrastructural deficiencies in the face of burgeoning populations.

Despite these differences, however, it is possible to offer a number of conclusions and recommendations for future urban policy research and practice. The increasing scale and impact of the restructuring process affecting the world's urban areas, together with the continuing scarcity of public resources, require a realistic appraisal of the problems and prospects for cities. Rather than attempting to recreate the historic economic base of many old industrial cities, policy must seek to exploit the new opportunities that emerge from the process of economic change.

Possibly the greatest challenge for urban policy concerns the distribution of the benefits and costs of urban restructuring. While the problems experienced by people and places marginal to the capitalist development process have deepened over recent decades, urban policy has proved incapable of remedying the situation. At the crux of the matter is the relative importance attached to social and economic priorities in national policy. The resolution of urban poverty and deprivation requires a complementary programme of 'people policies' operating over a long term at the structural level in order to achieve a redistribution of wealth in society, and more immediate local-level 'place policies' to improve the current position of the disadvantaged. The practical difficulties of implementing such policies should not be underestimated, particularly in states where economic and political elites enjoy a symbiotic relationship.

Varying degrees of ideological antipathy between capital and national and local states cannot disguise the fact that the magnitude of the urban crisis in both the developed and developing world is such that the successful restructuring of urban space, and in particular the revitalization of declining cities, requires capital investment from the private sector. It also requires a combination of traditional 'top-down' urban policies and community-based 'bottom-up' strategies (such as Community Development Corporations 
and Local Exchange Trading Systems) (Pacione, 2005). Policy makers must strike an appropriate balance between the demands of capital and the needs of people. While embracing the need for private sector investment in urban regeneration, the social deficiencies of property-led urban change must also be recognized. This was evident in the conflict between the goals of local residents and the aims of the Urban Development Corporation established in London's Docklands. The aim must be for urban policy to work with, but not for, capital.

The administrative structure of an urban region can influence the impact of policy. Metropolitan-wide government can overcome problems of fragmented decision making and via cross-subsidization can aid resource redistribution within an urban region. The merits of public participation, on the other hand, point to increased decentralization of government. The distribution of powers between different levels of government is a key issue. Urban policy makers must be prepared to experiment with new ideas when existing administrative arrangements prove unsatisfactory.

Academic research also has a role to play in forming future urban policy. Several important questions merit analysis. In view of the impact of 'non-urban' policies on cities, consideration could be given to the derivation of a method of urban impact analysis whereby the differential effect of public spending on distressed urban areas might be one component of decisions on whether to implement a particular policy. An important issue at a time of resource scarcity is the cost-effectiveness of policy and, in particular, the extent to which public expenditures succeed in generating private investment.

Finally, it is important to realize that contemporary urban problems are long term, multisectoral and global in scope. There are clear policy benefits to be derived from greater international cooperation. More systematic observation of cities throughout the world with different types of government, in different cultural realms, and at different stages of technological evolution could reveal recurring themes, uncover innovative policies and practices, and may suggest important new directions for urban policy and governance.

\section{References}

Adams, D. and C. Watkins (2002), Greenfields, Brownfields and Housing Development, Oxford: Blackwell.

Berry, B. (1985), 'Islands of renewal in seas of decay', in P. Peterson (ed), The New Urban Reality, Washington, DC: Brookings Institution, pp. 69-98.

Brundtland Commission (1987), Our Common Future, Oxford: Oxford University Press.

Budd, L. and S. Whimster (1992), Global Finance and Urban Living, London: Routledge.

Burchell, D., D. Listokin and C. Galley (2000), 'Smart growth', Housing Policy Debate, 11, 821-79.

Church, A. and M. Frost (1995), 'The Thames Gateway', Geographical Journal, 161(2), 199-209.

Claydon, J. and B. Smith (1997), 'Negotiating planning gains through the British development control system', Urban Studies, 34(2), 2003-22.

Collinicos, A. (2001), Against the Third Way, Cambridge: Polity Press.

Community Development Project (1997), Gilding the Ghetto, London: HMSO.

Cox, K. (1997), Spaces of Globalization: Reasserting the Power of the Local, New York: Guilford Press.

Crewe, L. and J. Beaverstock (1998) 'Fashioning the city: cultures of consumption and contemporary urban spaces', Geoforum, 29(3), 287-308.

Cullingworth, B. and R. Caves (2003), Planning in the USA, London: Routledge.

Cullingworth, B. and V. Nadin (2006), Town and Country Planning in the United Kingdom, London: Routledge.

Daniels, T. (1999), When City and Countryside Collide, Washington, DC: Island Press.

Eade, J. (1997), Living the Global City: Globalization as a Local Process, London: Routledge.

Edwards, J. and R. Batley (1978), The Politics of Positive Discrimination, London: Tavistock.

Etherington, D. and M. Jones (2004), 'Beyond contradictions of the workfare state', Environment and Planning $C, 22(1), 129-48$. 
Fainstein, N. and S. Fainstein (1982), Urban Policy Under Capitalism, Beverly Hills, CA: Sage.

Fainstein, S. (1994), The City Builders: Property, Planning and Politics in London and New York, Oxford: Blackwell.

Gaffiken, F. and B. Warf (1993), 'Urban policy and the post-Keynesian state in the United States and the United Kingdom', International Journal of Urban and Regional Research, 17(1), 67-84.

Gerber, E. and J. Phillips (2004), 'Direct democracy and land use policy', Urban Studies, 41(2), 463-79.

Giddens, A. (2000), The Third Way and its Critics, Cambridge: Polity Press.

Heinig, J. (1985), Public Policy and Federalism, New York: St Martin's Press.

Hill, D. (2000), Urban Policy and Politics in Britain, London: Macmillan.

HMG (1994), Sustainable Development: The UK Strategy, Cmd 2426, London: HMSO.

HMG (1999), A Better Quality of Life - Strategy for Sustainable Development for the UK, Cmd 4345, London: TSO.

HMG (2005), The UK Government Sustainable Development Strategy, Cmd 6467, London: HMSO.

Jackson, R. (1981), Land Use in America, London: Arnold.

Johnstone, C. and M. Whitehead (2004), 'Horizons and barriers in British urban policy', in C. Johnstone and M. Whitehead (eds), New Horizons in British Urban Policy, Aldershot, UK: Ashgate, pp. 3-21.

Judd, D. and T. Swanstrom (1998), City Politics: Private Power and Public Policy, London: Longman.

King, R. (1983), Capital and Politics, London: Routledge \& Kegan Paul.

Law, C. (2002), Urban Tourism, London: Continuum.

Lawless, P. (1988), 'British inner urban policy', Regional Studies, 22(6), 531-42.

Levine, M. (1987), 'Downtown redevelopment as an urban growth strategy: a critical appraisal of the Baltimore renaissance', Journal of Urban Affairs, 9(2), 133-8.

Levine, M. (1989), 'The politics of partnership', in G. Squires (ed.), Unequal Partnerships, New Brunswick, NJ: Rutgers University Press, pp. 12-34.

Levitas, R. (1998), The Inclusive Society, Basingstoke, UK: Macmillan.

Malone, P. (1996), City, Capital and Water, London: Routledge.

Martin, R. (1988), 'Industrial capitalism in transition', in D. Massey and J. Allen (eds), Uneven Redevelopment, London: Hodder and Stoughton, pp. 202-31.

McCarthy, J. (2003), 'Regeneration and community involvement: the Chicago empowerment zone', City, 7(1), 95-105.

McGreal, S. Berry, J. Lloyd and J. McCarthy (2002), 'Tax-based mechanisms in urban regeneration', Urban Studies, 39(10), 1819-31.

Merrifield, A. (1993), 'The Canary Wharf debate', Environment and Planning A, 25(9), 1247-65.

Mohan, G. (2000), 'Dislocating globalization: power, politics and global change', Geography, 85(2), 121-33

Mort, F. (1996), Cultures of Consumption, London: Routledge.

Nelson, R. (1980), Zoning and Property Rights, Cambridge, MA: MIT Press.

Oatley, N. (1996), 'Sheffield's cultural industries quarter', Local Economy, 11(2), 172-9.

Oatley, N. (1998), Cities, Economic Competition and Urban Policy, London: Paul Chapman.

Pacione, M. (1997), Britain's Cities: Geographies of Division in Urban Britain, London: Routledge.

Pacione, M. (2005), 'National and local responses to urban economic change', in M. Pacione, Urban Geography: A Global Perspective, London: Routledge, pp. 330-51.

Persky, J. and W. Weiwel (1994) 'The growing localness of the global city', Economic Geography, 70, 129-43.

Peterson, G. and C. Lewis (1986), Reagan and the Cities, Washington, DC: Urban Institute Press.

Sassen, S. (1994), Cities in the World Economy, London: Pine Forge Press.

Scott, A. (1997), 'The cultural economy of cities', International Journal of Urban and Regional Research, 21(2), $323-39$.

Smith, M. (1988), City, State, and Market, Oxford: Blackwell.

Smith, M. and J. Feagin (1987), The Capitalist City, Oxford: Blackwell.

Stegman, M. (1995), 'Recent United States urban change and policy initiatives', Urban Studies, 32(1), 1601-7.

Talen, E. (2005), New Urbanism and American Planning, London: Routledge.

Turok, I. (1992) 'Property-led urban regeneration: panacea or placebo?', Environment and Planning A, 24(3), $361-80$. 
M. Pacione - 9781849802024 